\title{
CYP1A2 Gene
}

National Cancer Institute

\section{Source}

National Cancer Institute. CYP1A2 Gene. NCI Thesaurus. Code C26519.

This gene plays a role in the oxidation/activation of procarcinogens. It is also involved in the metabolism of drugs and other xenobiotics. 